\title{
Colour and decay resistance and its relationships in Eperua grandiflora
}

\author{
Nadine AMUSANT ${ }^{1 *}$, Meriem FouRnIER $^{2}$, Jacques BEAUCHENE $^{3}$ \\ ${ }^{1}$ CIRAD - PERSYT - UR Valorisation des Bois Tropicaux, 73 rue Jean-François Breton, 34538 Montpellier Cedex 5, France \\ ${ }^{2}$ UMR LERFOB, INRA - INGREF 14 Avenue Girardet - CS 4216 - 54000 Nancy, France \\ ${ }^{3}$ UMR Ecofog - BP 701, Kourou, 97310 French Guiana
}

(Received 14 April 2008; accepted 2 August 2008)

Keywords:

natural durability /

colour /

decay resistance /

variability /

heartwood /

tropical wood

\begin{abstract}
- Eperua grandiflora, which is widely distributed in the French Guiana forest region, shows high variability in decay resistance. Further information concerning this wood quality parameter is necessary, but standard testing methods are complex and time-consuming. We assessed the use of colorimetry to determine durability in heartwood samples from a range of trees.

- Eperua grandiflora colour parameters were measured using a CIELAB system, revealing that the tree effect was greater than the radial position and height effects.

- The wood samples were exposed to Coriolus versicolor and Antrodia sp. according to two European standards (En 350-1 and XP CEN TS 15083-1). Eperua grandiflora is more susceptible to brown rot. These two standards did not give the same durability classes. The high variation in natural durability was due to the tree effect.

- These two properties were found to be correlated and the assessment also distinguished the extreme durability classes but they are not sufficient to classify the class of durability of this species.
\end{abstract}

Résumé - Étude de la variabilité de la couleur, de la durabilité naturelle et recherche de corrélations chez Eperua grandiflora.

- Eperua grandiflora, essence largement répandue dans les forêts de Guyane soufre d'un défaut majeur : une grande variabilité de sa durabilité naturelle à l'égard des champignons lignivores. Dans un premier temps, nous avons étudié la variabilité de la mesure de la couleur selon le système CIElab afin de vérifier si la colorimétrie peut être utilisée comme un indicateur de la durabilité naturelle.

- Nous avons étudié la résistance de cette essence à l'échelle inter, et intra-arbres à l'égard de Coriolus versicolor et Antrodia sp., conformément aux normes européennes en vigueur : EN 350-1 et XP TS 15083-1. Les résultats ont révélé qu'Eperua grandiflora est plus sensible au champignon de pourriture brune.

- De même, l'utilisation des normes a montré que l'on n'obtenait pas les mêmes classes de durabilité. La variabilité de la durabilité et de la couleur est plus importante à l'échelle inter-arbres qu'à l'échelle intra-arbre.

- Enfin, ces deux propriétés sont corrélées mais nous ne pouvons envisager d'utiliser la colorimétrie comme indicateur de la durabilité naturelle, car elle ne permet de différencier que les classes extrêmes.

\section{INTRODUCTION}

Some tropical forest species have interesting characteristics like natural durability, which is an essential property for wooden constructions and in situations where there is a high risk of fungus and insect infestation. In some cases, however, different wood pieces in a structure may not have the same natural durability due to intraspecific variability in natural durability. This problem has been noted in

* Corresponding author: nadine.amusant@ cirad.fr
Eperua grandiflora (Cesalpiniacae), which is found throughout the Guianian region and Amazon Basin. The study of the data base of CIRAD-Forêt (unpublished) shows that durability of this tree is highly variable, with the timber ranked in durability class 2 or 3 (durable to moderately durable). Several factors have been postulated to contribute to the variation in the natural durability of wood in different tree species. The same factors may also be partly responsible for variations between different stem sections and between individuals within durable species. The same is true for wood colour, which can 
vary greatly between different species and within the same species, between heartwood and sapwood and even in different parts of the tree (Amusant, 2003; Janin and Mazet 1987; Lavisci et al., 1989). Studies on wood colour variability have been focused on the anatomical elements, the woody framework of the species (fibres, vessels, extractives), the type of machining and the nature of light reflected from the wood surface (Burtin, 1994; Hiller et al., 1972; Wilkins et al., 1990). Physiological explanations for variations in heartwood colour have considered extractives like polyphenols or their precursors produced in the leaves, needles or cambium and transported by phloem and rays to the heartwood (Burtin et al., 1998; Da Costa et al., 1962; Mosedale et al., 1996b). These compounds supposedly then undergo chemical changes, thus leading to changes in heartwood colour. Differences in wood colour thus primarily reflect variations in the quantity and nature of wood extractives (Hillis, 1971). These compounds are also involved in wood durability to avoid fungal infestations, and differences in resistance correspond to variations in the quantity and quality of extractives. Some studies have shown that there is a relationship between colour measurements and decay resistance in some species (Boardman et al., 1992; Dumonceaud, 2001). The present study concerns study of colour measurements, decay resistance in Eperua grandiflora. The wood of this tree is brownish red and composed of polyphenolic and diterpenoic compounds (Blake and Jones, 1963; Villeneuve and Vergnet, 1988). The aim of this study was to assess variability in colour and decay resistance of a tree population from one site at intra-tree and inter-tree levels, and then to determine whether wood colour and durability are correlated. If these two properties are found to be correlated, colour measurements could be proposed as an indicator of decay resistance.

\section{MATERIAL AND METHODS}

Heartwood was obtained from nine trees in Paracou forest, French Guiana. The trees were 30-40 m high and growing in a natural stand. The average tree diameter was $42 \mathrm{~cm}$ (range $34-53 \mathrm{~cm}$ ). From each tree, six replicate samples $(50 \times 25 \times 50 \mathrm{~mm} \mathrm{R}, \mathrm{L}, \mathrm{T}$ directions) were taken (in the same axis) in the outer, intermediate and inner heartwood located 3 and $15 \mathrm{~m}$ from the tree base. The samples were stabilised at $12 \%$ moisture content.

\subsection{Colour measurements}

The blocks were conditioned at $20{ }^{\circ} \mathrm{C}$ and $65 \% \mathrm{RH}$ and stored in the dark to avoid colour modifications. Colour was measured on the radial (RL) side with a colorimeter (Datacolor Microflash $200 \mathrm{~d}$ ) at ambient temperature and humidity. The sensor head diameter was $6 \mathrm{~mm}$. Illuminant D65 and the $10^{\circ}$ standard observer were used as the measurement conditions. The surface observed was $59 \mathrm{~mm}^{2}$ and specular reflection setting was excluded. The reflectance readings were converted into $\mathrm{L}^{*}, \mathrm{a}^{*}, \mathrm{~b}^{*}, \mathrm{C}^{*}, \mathrm{~h}^{*}$ colour parameters, where $\mathrm{L}^{*}$ represents the lightness along the lightness axis $(100=$ white; $0=$ black), $a^{*}$ the redness $\left(a^{*}>0\right)$ or greenness $\left(a^{*}<0\right)$, B the yellowness $\left(b^{*}>0\right)$ and greenness $\left(b^{*}>0\right)$. The $h^{*}$ angle can be calculated as $\mathrm{h}^{*}=\operatorname{arctg}\left(\mathrm{b}^{*} / \mathrm{a}^{*}\right)$, so the hue angle circle $\mathrm{h}^{*}=0^{\circ}$ denotes redness and $h=90^{\circ}$ denotes yellowness. The $C^{*}$ saturation measuring the colour intensity can be calculated as $C^{*}=\left[\left(a^{*}\right)^{2}+\left(b^{*}\right)^{2}\right]^{1 / 2}$. Measurements on the radial side were conducted in triplicate and the data were averaged. The results were analysed via the $L^{*}, C^{*}, h^{*}$ parameters because they are easy to interpret. The total number of samples was 324 .

\subsection{Decay resistance measurements}

After the colour measurements, the wood samples obtained at $3 \mathrm{~m}$ height were used to determine the natural durability. Durability was assessed by exposing six replicates of outer, middle and inner heartwood from a tropical fungus (Antrodia sp. strain CTFT $57 \mathrm{~A}$ ) and Coriolus versicolor (strain CTBA $863 \mathrm{~A}$ ). The total number of samples was 162, while 20 additional samples (same dimensions) of beech and pine (Fagus sylvatica, Pinus sylvestris) were used to monitor fungal virulence. Samples were weighed (M1), sterilized (gamma ray) and then exposed to the fungi for 16 weeks under tropical conditions $\left(75 \% \mathrm{RH}\right.$ and $\left.27^{\circ} \mathrm{C}\right)$. After the decay exposure, all wood blocks were placed in the oven $\left(48 \mathrm{~h}, 103{ }^{\circ} \mathrm{C}\right)$ to determine the oven dry mass (MOf), and the percentage of mass loss (ML) based on the dry weight (M0i) was calculated.

For each tree, 10 wood blocks were used to establish the timber moisture content. After a conditioning period, the wood blocks were placed in the oven $\left(24 \mathrm{~h}, 103{ }^{\circ} \mathrm{C}\right)$ and weighed. The mean moisture content (MC) was used to calculate the initial dry mass (M0i) in each wood block

$$
\begin{aligned}
\mathrm{M}_{\mathrm{i}} & =\mathrm{M}_{1} \times 100 /(100+\mathrm{MC}) \\
\mathrm{ML} & =100 \times\left(\mathrm{M}_{\mathrm{i}}--\mathrm{M}_{\mathrm{f}}\right) / \mathrm{M}_{\mathrm{i}}
\end{aligned}
$$

where $\mathrm{MO}_{i}$ is the initial dry mass of the sample, $\mathrm{M}_{1}$ is the initial conditioned mass, $\mathrm{MC}$ is the moisture content, and $\mathrm{M} 0_{f}$ is the dry mass of the sample after exposure to the fungus. The durability rating against wood-destroying Basidiomycetes fungi is based on two standards:

- According to the guidance of the technical specifications of AFNOR (2006) to determine the "Durability of wood and woodbased products - Determination of the natural durability of solid wood against wood-destroying fungi, test methods - Part 1: Basidiomycetes".

- According to the guidance of NF EN 350-1 (AFNOR, 1992) and NF EN 113 (AFNOR, 1986).

As five durability classes proposed by the guidances are defined in relation to the median mass loss and relative mass loss obtained with the most destructive fungus.

\subsection{Statistical analysis}

The XLSTAT software package was used for the statistical analysis. The effects of radial position and height on wood colour at the intra-tree and inter-tree level and the effect of the radial position on wood decay at the intra-tree and inter-tree level were studied by analysis of variance (ANOVA). Both intra-tree and inter-tree levels were studied by analysis of the calculated Pearson correlation coefficients to determine the relationship between colour parameters and decay resistance. Values were considered to be statistically significant at $P<0.05$. 
Table I. Mean, range, standard deviation (SD), coefficient of variation $(\mathrm{CV} \%)$ of colour parameters for the nine trees $(n=324$ samples from nine trees)

\begin{tabular}{lccccc}
\hline Colorimetric parameters & Mean & SD & Min & Max & CV \\
\hline $\mathrm{L}^{*}$ & 56.1 & 3.2 & 46.8 & 64.0 & 5.8 \\
$\mathrm{C}^{*}$ & 35.9 & 2.7 & 24.5 & 40.3 & 7.7 \\
$\mathrm{~h}^{*}$ & 55.5 & 2.2 & 48.0 & 59.6 & 4.0 \\
\hline
\end{tabular}

\section{RESULTS}

\subsection{Colour measurements}

As shown in Table I, all the colorimetric parameters studied revealed inter-tree variations, especially with respect to the $\mathrm{L}^{*}$ and $\mathrm{C}^{*}$ parameters. For example, the average $\mathrm{L}^{*}$ parameter ranged from 46.8 (tree 2) to 64.0 (tree 3 ). The high part of the total variation for the colour parameters is explained when taking into account tree, radial position, height and interaction between them. From the different monitored sources of variation, the between-tree effect was greater in comparison to the radial position and height effects (Tab. II). The explained variability values were $48 \%$ for $\mathrm{L}^{*}, 51 \%$ for $\mathrm{C}^{*}$, and $58 \%$ for $\mathrm{h}^{*}$. The low percentage of variance obtained for the radial position effect could be explained by the presence of resin pockets which masked a more marked effect. A local measurement of wood samples with and without resin showed that the presence of resin make the wood darker and less red (data not supply). The residual variation was relatively low, i.e. under $20 \%$ for the $\mathrm{C}^{*}$ and $\mathrm{h}^{*}$ parameters, which means that the variability between matched samples was low. The significant interaction noted between all effects indicated that the general colour variation pattern from the inner to the outer heartwood and from the base to the upper part of the trunk did not apply to all the trees. The Student's $t$-test analysis of $\mathrm{L}^{*}, \mathrm{C}^{*}, \mathrm{~h}^{*}$ data revealed that the outer heartwood was not significantly different from the intermediary or inner heartwood, even at the 5\% level. Figure 1 illustrates the absence of colour differences for the $\mathrm{L}^{*}$ parameter between the different heartwood areas. However, with tree No. 3, No. 5 and No. 9, the inner and intermediary heartwoods were significantly darker and redder $(P<0.001)$ than the outermost heartwood according to the Student's $t$-test. Because of the low variation in tree diameter and the absence of information on tree age, we cannot conclude that the colour variation gradient was due to the tree age. We also compared the wood samples located at $15 \mathrm{~m}$ (top) and $3 \mathrm{~m}$ (bottom) stem height and the Student's $t$-test showed no significant difference.

Like the different wood characteristics, the colorimetric parameters depended on the tree effect. With regard to the significance of the tree effect, our results are in accordance with those of Dumonceaud (2001) with Castanea sativa, Rink (1987) with Juglans nigra and Klumpers and Jarin (1992) in Quercus robur. All trees originated from the same place, with no differences due to soil characteristics or site quality. Our results suggest that the origin (genetics) has a strong effect, which would explain the differences between trees with respect to the colorimetric parameters, in accordance with the results of several previous studies (Gierlinger et al., 2004, Mosedale et al., 1996a). The inter-tree difference of colour was also due to the tree age. In our case, it was not possible to determine the age of Eperua spp. trees because of the absence of marked growth rings. The weak tree diameter distribution not allows to analyse trees with a large age distribution and valid an age effect. The presence of extractives, particularly polyphenolics, plays an important role in wood colour (Dellus et al., 1997; Mosedale et al., 1996b). Eperua grandiflora contains terpenoids and polyphenolic compounds (Blake and Jones, 1963; Villeneuve and Vergnet, 1988). When the heartwood colour is slightly red, polyphenolic compounds are mostly responsible for determining this trait. The quantity and quality of extractives varies at inter- and intra-tree levels (Klumpers and Janin, 1992; Klumpers et al., 1993). The relations observed in some trees between colorimetric parameters and the radial position was due to the wood age. Duraminisation and the ageing process play an important role in the variability in the extractive content and explain $80 \%$ of the variation in some properties at the intra-tree level (Masson et al., 1995). However, in our study, the presence of resin pockets hampered measurement of the impact of polyphenol compounds.

\subsection{Decay resistance measurements}

The mean mass losses in the beech and pine control samples were $55 \%$ for Antrodia sp. and 44\% for Coriolus versicolor. These values were higher than the minimal value indicated in the standards, which indicates that the fungi were very virulent under tropical conditions and validates the durability test results. Table III presents means, ranges, standard deviations and coefficients of variation in mass loss with Coriolus versicolor and Antrodia sp. Eperua grandiflora is very durable against the white rot fungus Coriolus versicolor. With Antrodia sp., the mean mass loss was close to $15.6 \%$. The mass losses caused by Antrodia sp. ranged from $1.35 \%$ (tree 5) to $32.21 \%$ (tree 4), suggesting a tree effect. According to the classification of both standards, under the climatic conditions of this study, Eperua grandiflora was ranked in class 2 (durable) with EN 350-1: most of the samples were durable (47\%) and moderately durable $(45 \%)$, while $34 \%$ of the wood samples were moderately durable and $53 \%$ were slightly durable according to XP CEN TS 15083-1 (Tab. IV). These results showed the high variability in natural durability of Eperua grandiflora as compared to Antrodia sp. Both standards did not generate the same durability class. This difference is due to the fact that with EN 350-1, the calculations take into account the value of the virulence to calculate a relative mass loss while XP CEN TS 15083-1 used a median mass loss without any correction to determine the durability class. Under tropical conditions, XP CEN TS 15083-1 was more suitable for determining the natural durability against fungal attack. When taking the high fungal virulence values into account, the durability classification was less severe. Further field tests will be necessary to confirm the durability class.

The variance analysis was carried out and the ANOVA results and total variation decomposition are shown in Table V. When taking the tree, radial position and interaction between 
Table II. $\mathrm{L}^{*}, \mathrm{C}^{*}, \mathrm{~h}^{*}$ analysis of variance of the "tree-radial position-height" and interaction ("tree $\times$ radial position" ; "tree $\times$ height", "radial position $\times$ height" ; "tree $\times$ radial position $\times$ height").

\begin{tabular}{|c|c|c|c|c|c|c|c|c|c|c|}
\hline & & & $\mathrm{L}^{*}$ & & & $\mathrm{C}^{*}$ & & & $\mathrm{~h}^{*}$ & \\
\hline $\begin{array}{l}\text { Source of } \\
\text { variation }\end{array}$ & $\begin{array}{l}\text { Degree of } \\
\text { freedom }\end{array}$ & $\begin{array}{l}\text { Mean } \\
\text { square }\end{array}$ & $P>F$ & $\begin{array}{c}\% \\
\text { variance }\end{array}$ & $\begin{array}{l}\text { Mean } \\
\text { square }\end{array}$ & $P>F$ & $\begin{array}{c}\% \\
\text { variance }\end{array}$ & $\begin{array}{l}\text { Mean } \\
\text { square }\end{array}$ & $P>F$ & $\begin{array}{c}\% \\
\text { variance }\end{array}$ \\
\hline Tree & 8 & 206.9 & $<0.01 \%$ & 48 & 160.47 & $<0.01 \%$ & 51.0 & 117.52 & $<0.01 \%$ & 58.3 \\
\hline Height & 1 & 17.2 & $<0.01 \%$ & 2.0 & 32.70 & $<0.01 \%$ & 1.3 & 0.99 & $<0.01 \%$ & 0.06 \\
\hline Tree $\times$ height & 8 & 13.45 & $<0.01 \%$ & 3.1 & 3.15 & $<0.01 \%$ & 1.0 & 5.19 & $<0.01 \%$ & 2.6 \\
\hline Tree $\times \mathrm{RP}^{*}$ & 16 & 15.05 & $<0.01 \%$ & 7.0 & 27.33 & $<0.01 \%$ & 17.4 & 11.07 & $<0.01 \%$ & 11.0 \\
\hline Error & 270 & 3.95 & & 31.11 & 1.47 & & 15.8 & 1.12 & & 18.7 \\
\hline Total & 323 & & & 100 & & & 100 & & & 100 \\
\hline
\end{tabular}

${ }^{*} \mathrm{RP}=$ Radial position.

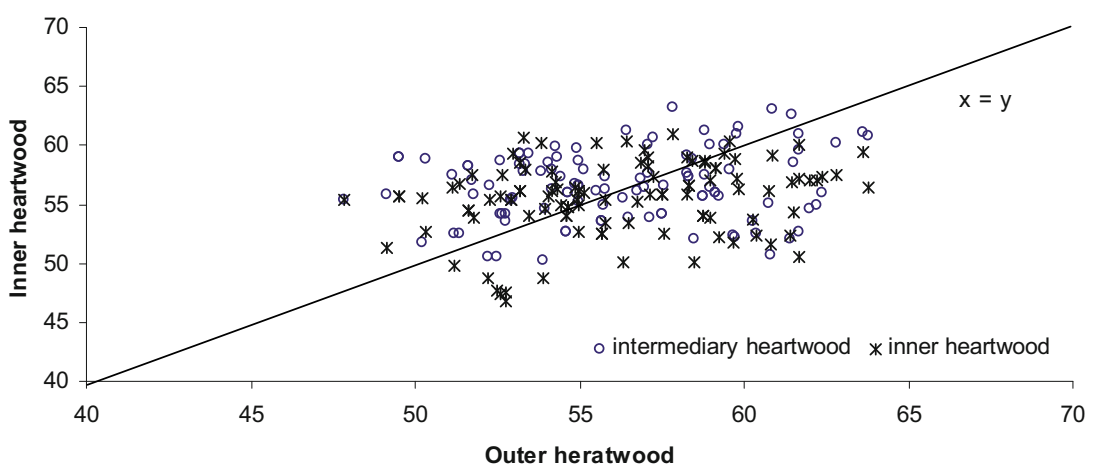

Figure 1. Relationships between outer, intermediary and inner heartwood for $\mathrm{L}^{*}(n=324)$.

Table III. Means (\%), ranges, median standard deviation (SD) coefficient of variation (CV\%) of mass losses with Coriolus versicolor and Antrodia sp. ( $n=162$ samples from nine trees).

\begin{tabular}{lccccccc}
\hline Fungi & $n$ & Mean & Median & SD & Min & Max & CV \\
\hline Antrodia sp. & 162 & 15.6 & 15.2 & 5.3 & 1.3 & 32.2 & 34.0 \\
Coriolus versicolor & 162 & 1.95 & 1.6 & 1.33 & 0.10 & 7.5 & 0.67 \\
\hline
\end{tabular}

them into account, the variability between trees was the most important effect, i.e. it explained $45 \%$ of the total variability and there was a relatively low residual variation level. The "tree $\times$ radial position" interaction explained $32 \%$ of the variation. Analysis of the decay resistance by the Student's $t$-test showed that the outer heartwood was not significantly different from the intermediary and inner heartwood, even at the $0.5 \%$ level, because of the high variability in the results. With regard to the significance of the tree effect, our results are in agreement with those obtained previously by, Freitag and Morell (2000) with Thuja plicata and Dumonceaud (2001) with Castanea sativa. Like the colour parameters, the decay resistance variability could be explained by several factors like a genetic effect, the genotype influences several characters like the amount of heartwood and decay resistance of wood. This phenomenon was demonstrated by Viitanen et al. (1998) and Venäläinen et al., (2001) in Larix sibirica. Tree age also has a marked effect. Generally young trees have a high propor-
Table IV. Natural durability classification of wood samples from Eperua grandiflora according to EN 350-1 and XP CEN TS 15083-11.

\begin{tabular}{|c|c|c|}
\hline & $\begin{array}{l}\text { Classification according } \\
\text { to En XP CEN TS 15083-11 }\end{array}$ & $\begin{array}{c}\text { Classification according } \\
\text { to NF EN } 350-1\end{array}$ \\
\hline Very durable & $5 \%$ & $8 \%$ \\
\hline Durable & $8 \%$ & $47 \%$ \\
\hline Moderately durable & $34 \%$ & $45 \%$ \\
\hline Slightly durable & $53 \%$ & $0 \%$ \\
\hline Not durable & $1 \%$ & $0 \%$ \\
\hline
\end{tabular}

tion of juvenile wood and an early formed heartwood, which is less durable than the heartwood in mature trees (Bhat, 1998; Guglielmo, 1981). In this study, it was difficult to determine the age of trees because in tropical conditions trees grow continuously, hence we could not evaluate the effect of age in the durability variability at the inter-tree level. The natural decay resistance of wood is dependant on the amount and quality of primary metabolites and on the storage of extractives deposited in the heartwood (Delaveau and Vidal-Tessier, 1988; Zabel and Morell, 1992). These substances inhibit the primary metabolism of fungi or the degradation process that they trigger, and their content increases with the tree age (Hillis, 1987; Nault, 1988; Posey and Robinson, 1969). These results agree with those obtained with other temperate species 
Table V. Decay resistance analysis of variance of "tree and radial position" and interaction "tree $\times$ radial position" - Antrodia sp. (\%).

\begin{tabular}{lccccc}
\hline Effects & $\begin{array}{c}\text { Degree } \\
\text { of freedom }\end{array}$ & $\begin{array}{c}\text { Mean } \\
\text { square }\end{array}$ & F & $P>F$ & $\begin{array}{c}\% \\
\text { variance }\end{array}$ \\
\hline Trees & 8 & 257.08 & 48.75 & $<0.01$ & 45 \\
Radial position & 2 & 180.50 & 34.23 & $<0.01$ & 8 \\
Trees $\times$ radial position & 16 & 90.84 & 17.22 & $<0.01$ & 32 \\
Error & 135 & 5.27 & & & 15 \\
Total & 161 & & & & 100 \\
\hline
\end{tabular}

(Gartner et al., 1999, Guilley et al., 2004). Decay variations were due to the presence of extractives formed between the sapwood and the outermost, to the duraminisation and ageing process. Extractives in the outermost heartwood are present in greater quantity and more toxic and they decrease and lose their toxicity near the crown of the stem (Reis, 1973).

From an experimental standpoint, the choice of standard and the bioassay conditions are very important in wood durability classification. Heterogeneous results have a negative impact on wood uses. The results obtained in tropical conditions with tropical fungi were clearly worse than those obtained with European standards. When the wood is to be used in tropical conditions, decay resistance should be monitored under the same conditions in order to be close to the actual situation. In tropical conditions, the decay resistance of Eperua grandiflora was found to be variable and the median mass loss obtained from XP CEN TS 15083-1 should be considered in order to avoid disappointing end users. It is thus important to find indicators that could accurately predict durability.

\subsection{Relation between colour and durability}

Because of the high variability in natural durability, it would be interesting to propose an indicator that could be used to classify the natural durability of wood pieces for end users. Some correlation coefficients between colour coordinates and decay resistance are listed in Table VI. Correlation coefficients calculated with all values $(n=162)$ were low but significant (Pearson's correlation coefficients: 0.22 for $\mathrm{L}^{*}, 0.18$ for $\mathrm{C}^{*}$ and 0.46 for $\left.\mathrm{h}^{*}\right)$. The correlation coefficients calculated for each tree shows that significant Pearson correlations were obtained for some of the trees (No. 1-2-7-8-9), but the correlations differed according to the trees. We noted that redder wood was more resistant. A stepwise multilinear regression (stepwise criteria: probability of $F$ to enter $\leq 0.05 \%$ of to remove $\geq 0.1$ ) analysis was carried out to predict mass loss with two colour coordinates $\left(\mathrm{L}^{*}\right.$ and $\left.\mathrm{h}^{*}\right) . R^{2}$ was 0.26 and the standard error of the estimate was 4.58. The Fisher test results validated the model and the Student's t test results indicated that the constant was also significant. The contingency table (Tab. VII) obtained between the measured and predicted mass losses according to the different durability classes showed that the measured colorimetric parameters were effective for classifying $22 \%$ of the wood samples. Kokutse et al., 2006 find also a positive correlation between decay resistance and colour with
Table VI. Pearson correlation coefficients for colour values $\left(\mathrm{L}^{*}, \mathrm{C}^{*}\right.$, $\left.\mathrm{h}^{*}\right)$ and decay resistance against Antrodia sp. $(P<5 \%)$.

\begin{tabular}{lccc}
\hline Decay tests & $\mathrm{L}^{*}$ & $\mathrm{C}^{*}$ & $\mathrm{~h}^{*}$ \\
\hline All the trees (9) & 0.22 & 0.18 & 0.46 \\
Tree 1 & $\mathrm{ns}$ & $-0,50$ & 0,23 \\
Tree 2 & $\mathrm{ns}$ & $-0,55$ & 0.45 \\
Tree 3 & $\mathrm{ns}$ & $\mathrm{ns}$ & $\mathrm{ns}$ \\
Tree 4 & $\mathrm{~ns}$ & $\mathrm{~ns}$ & $\mathrm{~ns}$ \\
Tree 5 & $\mathrm{ns}$ & $\mathrm{ns}$ & $\mathrm{ns}$ \\
Tree 6 & $\mathrm{ns}$ & $\mathrm{ns}$ & $\mathrm{ns}$ \\
Tree 7 & +0.81 & +0.56 & +0.88 \\
Tree 8 & $\mathrm{ns}$ & $-0,58$ & $\mathrm{~ns}$ \\
Tree 9 & -0.60 & $-0,60$ & +0.63 \\
\hline
\end{tabular}

Table VII. Contingency table ( $\mathrm{M}=$ moderately; $\mathrm{S}=$ slightly). Number of samples $=162$.

\begin{tabular}{lccccc}
\hline \multicolumn{5}{c}{$\begin{array}{c}\text { Predicted mass loss } \\
\text { Calculated } \\
\text { mass loss }\end{array}$} & \multicolumn{4}{c}{$\begin{array}{c}\text { Very } \\
\text { durable }\end{array}$} & Durable & $\begin{array}{c}\text { M } \\
\text { durable }\end{array}$ & $\begin{array}{c}\text { S } \\
\text { durable }\end{array}$ & $\begin{array}{c}\text { Not } \\
\text { durable }\end{array}$ \\
\cline { 2 - 6 } & & 5 & & & \\
& Very durable & 4 & 4 & & \\
& Durable & 13 & 20 & & \\
& M durable & 12 & 40 & & \\
& S durable & & 1 & \\
Not durable & & & & \\
\hline
\end{tabular}

Teak, particularly with $\mathrm{L}^{*}$ parameter which explained $30 \%$ of the variation. In conclusion, the method was not suitable and had the drawback of outclassing a high number of the wood samples. The first results on the prediction of decay resistance based on colour parameters are encouraging, but colour measurement cannot be the only element considered for predicting decay resistance. It would be interesting to combine methods like infrared or near-infrared spectroscopy to improve the predictions like with Larch species (Gierlinger et al., 2003). Wood colour and decay resistance were found to be related with the extractive content. In a future study, it would be interesting to investigate the phenol compound content in relation with the colour and decay resistance and to evaluate the impact of the resin pockets.

\section{CONCLUSIONS}

This study confirmed that the tree effect had a very marked impact on decay resistance and colour measurements in Eperua grandiflora as compared to the radial position and height effects. Many of the individual wood species were found to be durable to moderately durable according to EN 350-1 and moderately durable to slightly durable according to XP CEN TS 15083-1 This difference in classification is very important when considering future use of this species in tropical conditions. Further field tests are necessary to determine the long-term performance. The best correlation between colour parameters and decay resistance was obtained with the $\mathrm{h}^{*}$ parameter (hue angle): redder wood was found to be more resistant. The correlation between the colour parameters and decay resistance is encouraging but not sufficient to classify wood by 
durability class. Combining colour measurements with spectral analysis results would enhance the identification of different durability classes and thus broaden the scope for use of this important resource in French Guiana. It will be also interesting to have more information about the quantitative proportion of resin pockets in the wood in order to better take into account the impact on colour measurements.

\section{REFERENCES}

AFNOR, 1986. Norme EN 113. Produits de préservation des bois Détermination du seuil d'efficacité contre les champignons basidiomycètes lignivores cultivés sur milieu gélosé.

AFNOR, 1992. Norme NF EN 350-1. Durabilité des bois et des matériaux dérivés du bois - Durabilité naturelle du bois massif.

AFNOR, 2006. Norme XP CEN TS 15083-1. Durability of wood and wood-based products - Determination of the natural durability of solid wood against wood-destroying fungi, test methods - Part1: Basidiomycetes.

Amusant N., 2003. Durabilité naturelle et couleur des bois de Guyane : mesure, variabilité, déterminisme chimique - application à Dycorynia guianensis, Sextonia rubra, Eperua grandiflora, Eperua falcata. Thèse de Doctorat, École Nationale du Génie Rural, des Eaux et Forêts, 227 p.

Bhat K.M., 1998. Properties of fast-grown teak wood: impact on enduser's requirements. J. Trop. For. Prod. 41: 1-10.

Blake S.G. and Jones J., 1963. Extractives from Eperua falcata: The petrol-soluble constituents. J. Chem. Soc. 85: 430-433.

Boardman B.E., Senft J.F., Mc Cabe G.P., and Ladisch C., 1992. Colorimetric analysis in grading black walnut veneer. Wood Fiber Sci. 24: 99-107.

Burtin P., 1994. Le déterminisme de la couleur du bois de chêne. Étude sur les relations entre la couleur et des propriétés physiques, chimiques et anatomiques ainsi que des caractéristiques de croissance. Thèse de doctorat, École du Génie Rural, des Eaux et des Forêts, Centre de Nancy, $195 \mathrm{p}$.

Burtin P., Jay-Allemand C., Charpentier J.P., and Janin G., 1998. Natural wood colouring process in Juglans sp. (J. nigra, J. regia and hybrid $J$. nigra $23 \times J$. regia) depends on native phenolic compounds accumulated in the transition zone between sapwood and heartwood. Trees 12: $258-264$.

Da Costa E.W.B., Rudman P., and Deverall J.J., 1962. Inter-tree variation in decay resistance of karri (Eucalyptus diversicolor F. Muell.) as related to colour, density and extractives content. J. Wood Sci. 10: $48-55$.

Delaveau P. and Vidal-Tessier A.M., 1988. Constituants secondaires à activité biologique du bois de quelques espèces tropicales. Bull. Soc. Bot. Fr. 3: 25-36.

Dellus V., Scalbert A., and Janin G., 1997. Polyphenols and colour of Douglas fir heartwood. Holzforschung 51: 291-295.

Dumonceaud O., 2001. Utilisation de petits bois naturellement durables dans des usages extérieurs (aire de jeux, mobilier urbain...) en substitution aux bois traités par des pesticides comme les solutions cuivre-chrome-arsenic. Thèse de doctorat, Université de Montpellier II, $210 \mathrm{p}$.

Freitag C.M. and Morrell J.J., 2000. Durability of a changing Western red cedar resource. Wood Fiber Sci. 33: 69-75.

Gartner B.L., Morell. J.J., Freitag C.M., and Spicer C., 1999. Heartwood decay resistance by vertical and radial position in Douglas-fir trees from a young stand. Can. J. For. Res. 29: 1993-1996.

Gierlinger N., Jacques D., Grabner M., Wimmer R., Schwanninger M., Rozenberg P., and Pâques L.E., 2004. Colour of larch heartwood and relationships to extractives and brown-rot decay resistance. Trees 18: 102-108.
Gierlinger N., Jacques D., Schwanninger M., Wimmer R., Hinterstoisser B., and Paques L.E., 2003. Rapid prediction of natural durability of larch heartwood using Fourrier transform near-infrared spectroscopy. Can. J. For. Res. 33: 1727-1736.

Guglielmo G., 1981. Technologia del legno. Vol 1. Ed. UTET, Turin, Italy, $126 \mathrm{p}$.

Guilley E., Charpentier J.P., Ayadi N., Snakkers G., Nepveu G., and Charrier C., 2004. Decay resistance against Coriolus versicolor in sessile oak (Quercus petraea Liebl.): analysis of the between-tree variability and correlations with extractives, tree growth and other basic wood properties. Wood Sci. Technol. 38: 539-554.

Hiller C.H., Freese F., and Smith D.M., 1972. Relationships in black walnut heartwood between color and other physical and anatomical characteristics. Wood Fiber Sci. 4:38-42.

Hillis W.E., 1971. Distribution, properties and formation of some wood extractives. Wood Sci.Technol. 1971: 273-289.

Hillis W.E., 1987. Heartwood and tree exudates. Springer-Verlag, 268 p.

Janin G. and Mazet J.F., 1987. Mesure de la variabilité de la couleur du bois. Nouvelle méthode appliquée aux carottes de sondage. Ann. Sci. For. 44: 119-126.

Klumpers J. and Janin G., 1992. Influence of age and annual ring width on the wood colour of oaks. Holz Roh- Werkst. 50: 167-171.

Klumpers J., Janin G., Becker M., and Levy G., 1993. The influences of age, extractives content and soil water on wood colour in oak: the possible genetic determination of wood colour. Ann. Sci. For. 50(Suppl.): 403s-409s.

Kokutse D., Stockes A., Baillere H., Kokou H., and Baudasse C., 2006. Decay resistance of Togolese teak and relationship with colour. Trees 20: 219-223.

Lavisci P., Janin G., and Uzielli L., 1989. Qualité du bois de six essences du maquis méditerranéen. Forêt Méditerr. X: 69-77.

Masson G., Moutounet M., and Puech J.L., 1995. Ellagitannin content of oak wood as function species and of sampling position in the tree. Am. J. Enol. Vitic. 46: 262-268.

Mosedale J.R., Charrier B., Crouch B., Janin G., and Savill P.S., 1996 . Variation in the composition and content of ellagitannins in the heartwood of European oaks (Quercus robur and Quercus petrae). A comparison of two French forests and variation with heartwood age. Ann. Sci. For. 53: 1005-1018.

Mosedale J.R., Charrier B., and Janin G., 1996b. Genetic control of wood colour density and heartwood ellagitannin concentration in European oak (Quercus petraea and Q. robur). Forestry 69: 112-124.

Nault J., 1988. Radial distribution of thujaplicins in old growth and second of Western Red Cedar (Thuja plicata D. Don.). Wood Sci. Technol. 22: 73-80.

Posey C.E. and Robinson D.W., 1969. Extractives of shortleaf pine: an analysis of contributing factors and relationship. TAPPI J. 52: 110115.

Reis M.S., 1973. Variation in decay resistance of four wood species from south eastern Brazil. Holzforschung 27: 103-111.

Rink G., 1987. Heartwood color and quantity variation in a young black walnut progeny test. Wood Fiber Sci. 19: 93-100.

Venäläinen M., Harju A.M., Nikkanen T., Paajanen L., Velling P., and Viitanen H., 2001. Genetic variation in the decay resistance of Siberian larch (Larix sibirica Ledeb.) wood. Holzforschung 55: 1-6.

Viitanen H., Paajanen T., Nikkanen T., Vellin P., 1998. Decay resistance of Siberian larch wood against brown rot fungi, Part 2 The effect of genetic variation. IRG/WP98-10287, 12 p.

Villeneuve F.A. and Vergnet M., 1988. Etudes des flavanes d'une essence tropicale (Eperua falcata). Bull. Soc. Bot. Fr. 3:19-24.

Wilkins A.P. and Stamp C.M., 1990. Relationship between wood colour, sylvicultural treatment and rate of growth in Eucalyptus grandis Hill (Maiden). Wood Sci. Technol. 24: 297-304.

Zabel R.A. and Morell J.J., 1992. Wood microbiology - Decay and its prevention. Academic Press, 476 p. 